\title{
Reasons for the formation of historical Kyiv as a sacral center
}

\author{
Olha Bachynska
}

\author{
Kyiv National University of Construction and Architecture \\ Povitroflotskyy Avenue 31, Kyiv, Ukraine, 03037 \\ olga-polosatik@ukr.net, orcid.org/0000-0002-5039-3100
}

Received 08.10.2018, accepted for publication 10.09.2018

DOI: 10.26884/uwt1808.1903

The buildings of Kyiv until 1917 are the object of research. Formation of buildings and dominants in planning structure of Kyiv is the subject of research. The reasons and the specifics of the formation of Kyiv until 1917 are as a sacral center with a dominant religious function is the purpose of the study. The analysis of the construction activity in the territory of Kyiv in each period of history and the comparison of the results of the activity are the research methods. The influence of historical events on the construction and architecture of temples in Kyiv was investigated earlier [1, 2]. The problem why Kyiv was formed as a sacred center was not considered.

The history of Kyiv has its own specificity, which distinguishes the city from other settlements. The time until 1917 can be divided into three major periods. Each of these periods has its own uniqueness and is different from others. This distribution may not coincide with the generally accepted due to the importance of local events that have influenced construction activities. Periods of buildings and development of Kyiv are Kyivan Rus, Lithuanian-Polish and Russian Empire. Each of them had a time when the city was actively developing, and the time of destruction from natural disasters, epidemics, internecine wars and attacks of foreign armies. It is because of this that a certain character of the Kyiv city structure has developed.

The culture of Kyivan Rus was based on the Orthodox religion. Education, cultural life developed around temples and monasteries.
The production of goods was either at home or in churches and monasteries. There were few public buildings in Kyiv.

The architectural dominant in building should be the main object, stand out by forms and height, and attract people. Other public buildings and places in Kyiv could not compete with temples. The temples were the most important; they had a unique image, a considerable height. Orthodox monasteries, cathedrals and churches were dominant in Kyiv during the years of Kyivan Rus. Religious life and religious events, cultural life, studies, most of the production of goods, management of the country's prince in most were concentrated in the main temples of the city. The temples carried many functions and were the main buildings in Kyiv.

Catholicism was a state religion in Lithuania and Poland. The city developed poorly in the Lithuanian-Polish period. Public buildings were erected little. Lithuanian princes banned the construction of Orthodox churches, but built Catholic temples. At the end of the period, the Kyiv Orthodox Metropolitan was able to reconstruct many destroyed temples that remained from the time of Kyivan Rus.

Orthodoxy with the center in Moscow was a state religion in Russia. Emperors in Russia believed that their Orthodox Church began from Kyiv and the period of Kyivan Rus. The Russian Empire honored Kyiv as a sacred city and built many Orthodox churches from small to large. Circuses, theaters, shops, museums, universities, management and business 
buildings, military buildings began to be built in the city only in the late 19th century. Buildings were placed on a red line, and therefore they did not stand out from the buildings. The temples continued to be dominant in the buildings. Thus, the domination of religious buildings remained during the history of the city until 1917.

Row buildings were in Kyiv except dominants. It was a large part of the city. Various residential buildings were a typical building in Kyivan Rus. Peasants lived in poor homes - dugouts and anointed huts. In the cities there were more expensive houses two-storeyed, from trunks of trees, with utility rooms. Kyiv was the capital of the state, a rich city. It is located in the forest zone. In Kyiv, wood was used as building material for defensive and residential buildings. That is why in the times of Kyivan Rus, the typical building in the city was a wooden two-story building. These were reinforced feudal farms with many buildings and facilities for owners, servants, domestic animals and production of goods. During the Lithuanian-Polish period, the city did not develop; therefore, anointed huts appeared in Kyiv. They differed from home in the village because they had a small plot. One and two-story brick houses and mansions were built with the development of the city. Such a building was characteristic of Kyiv almost to the beginning of the 20th century. Profitable seven-story houses began to be built in the city only at the end of the 19th century because of the city's suffering from natural disasters, wars and politics. They were built to rent a house. Considerable height, large forms and domes distinguished the temples over low residential and public buildings.

The relief on which the city was located influenced the formation of the buildings and general plan as well. Kyiv is located because of the need for defense on a large number of hills with steep slopes and deep depressions between them. Construction technologies at that time allowed the construction of more or less flat areas. Slopes with periodic landslides remained uninhabited. Therefore, the forms of the hills of Kyiv completely controlled the directions of development and forms of the general plan, the location of areas and settlements. Ancient temples and monasteries served not only cultural centers. They were defensive complexes with fortified walls around the area of the monastery or temple. Most of the temples and monasteries were located on high hills, so that it was easier to defend themselves from the enemy. When the guests drove to Kyiv, they saw golden domes of temples at the top of the hills from a great distance. Golden domes among the green trees on the tops of the hills impressed guests with beauty.

Kyiv has become a sacred city due to several factors. History has influenced the significant development of the sacred function. Sacral function and temples were important in the city during the times of Kyivan Rus. Then the city almost did not develop and the temples retained the dominant role in the buildings. Their number has become larger thanks to the Russian Empire. When other buildings began to be built in the city, the methods of building the city preserved the domination of the temples. The location of the temples on the hills made an unforgettable impression on the guests of the city.

Keywords: Kyiv, buildings, history, temples, dominant.

\section{REFERENCES}

1. Sukach M., 2017. Third international scientifically-practical conference Underwater Technologies 2017. Underwater Technologies, Vol.06, 3-15.

2. Bachynska O.V., 2017. Influence of historical events on construction of temples in Kyiv till 1917. Underwater Technologies, Vol.07, 96105. 